\title{
Laboring to Choose, Choosing to Labor: Coercion and Choice in the Potosi Mita
}

\author{
Matthew Smith
}

The Spanish colonial labour regime in Latin America was knou'n as the mita, and provided the Indian workers needed for mumerous Spanish enterprises. The best known of the mira instimutions was the Potosi mila, which lasted from 1573 10 1825. It diafted male Indians from the Vicerolaln' of Peru to work in the huge Spanish silier mines at Potosi. The mita placed a heany burden on the backs of Indian peasants, and adversel! affected village life. since many lindians migrated to escape the harsh conditions of the mines. liet while the Indians suffered as a result of Spanish colonial oppression, it would be a mistake to see them simply as passive victims; in fact, they exercised personal agenc! in a number of significant ways. One of these wans was by choosing whether to go to the mines or to migrate. Another way was by deciding either to leare Potosi afier sencing their time of forced labour or to stay on as volumany workers. which had considerable economic benefins; and indeed, many of them elected to stan: Ironically: in giving the lindians this latter choice, the coercion of the Potosi mita ended up creating the voluman long-term labour force that the Spanish had hoped for from the start.

"In the circuit of the Charcas, there is such abundance of Silver Mines, that they alone, if there were no other in the world, were sufficient to fill it with riches: in the middle of this jurisdiction stand the wonderfil mommains of Potosi, of whose treasure all Nations of the world have liberally participaled; the excellencies. . surmount any other thing in the old or new world, that they very well deserve a particular histony to eternize their fame. " - Albaro Alonso Barba

[The Potosi mining industry is] "a harsh execurioner of lindians, for each day' it consumes and destro!'s them, and their lives are made miserable by fear of death. ${ }^{.2}$ - Luis Capoche

\section{Introduction}

\footnotetext{
'Albaro Alonso Barba. The First Book of the Art of Metals in IITich is Declared the Manner of Their Generation and the Conconitants of Them (London: Printed for S. Meanme Bookbinder to the King's Most Excellent Majesty. 1669). 116.

2 Peter Bakewell. Miners of the Red Moumtain (Albequerque: University of New Mexico Press. 1984). 145.
} 
The institution of the colonial Latin American draft labour system known as the misa has been called "one of the most remarkable economic institutions devised by the wit of man." ${ }^{3}$ While the mita provided labour for agriculture. ${ }^{4}$ building and road construction, ranching, manning tambos (rest stops for official government travelers). and other tasks, ${ }^{3}$ the most famous (or infamous) mita institution was the Potosi mita which lasted from 1573, when it was adopted by Viceroy Francisco de Toledo, to 1825, when Latin American revolutionary Simon Bolivar abolished it. ${ }^{6}$ The Potosi mita drafted male Indians from seventeen provinces in the Viceroyalty of Peru to work in Potosi's silver mining industry.

The Potosi mita had a profound and complex impact on the lives of the mirạos (the Indians who were drafted) as well as on their families and communities. While individual families and communities struggled both physically and psychologically to accommodate the seemingly insatiable demands of the mita for Indian labour and monetary tribute, the mass migration of Indians who fled their traditional lands in order to escape mita obligations was perhaps the most important social impact of this labor regime. ${ }^{8}$ The provinces affected by the mita were depopulated and the forasteros (Indians who had left their traditional lands and kin groups) had to adapt culturally and socioeconomically in order to survive. Those who remained in the communities affected by the mita were obligated to compensate the Potosi mining industry for those mitayos who had fled (either by supplying replacement workers or enough money to pay for replacement workers) and thus their burdens were increased.

Nevertheless. the mita was not the only source of labour for the Potosi silver mines. Mingas. an Andean term for voluntary worker, also provided labour for the silver industry (peninsular Spaniards, Creoles, and African slaves did not labour in the mines. although the Spanish often held supervisory roles). The relationship between mingas and mitayos with regards to working conditions, wages. living conditions. and responses to the mita has reshaped the debate that emerged during the 1980 s between historian Steve Stern and economist Emmanuel Wallerstein about the nature of the Latin American economy. While

${ }^{3}$ D. A. Brading and Harry E. Cross. "Colonial Silver Mining: Mexico and Peru." Hispanic American Historical Revien. (H.AHR) 52 (1972): 558.

+ Irving A. Leonard. Colonial Travelers in Lasin America (New York: Alfred A. Knopf, 1972). 102.

solnn Howland Rowe. "The Incas Under Spanish Colonial Institutions." HAHR 37 (1957): 170.

${ }^{6}$ Jeffrey A. Cole. The Polosi Mita, 1573-1700 (Stanford: Stanford University Press, 1985), 1.

${ }^{7}$ Ibid.. 17.

${ }^{8}$ Ann M. Wightman. Indigenous Migration and Social Change (Durham: Duke University Press. 1990). 50. 
Wallerstein suggested that the mineowners retained control over the labour system and that Latin America fit into contemporary global patterns." Stern stressed that the existence of Indian agency led to the development of a unique labour system in which Indians had some control over their economic fate. Although Stern was correct in stating that Potosi's economy was unique. his assertion that Indians were masters of their own economic destiny is somewhat misleading. There were voluntary Indian labourers or mingas in Potosi. but most of them ended up in their "voluntary" occupation due to the deprivations and restrictions of the mita. In other words. the economic and social conditions enforced by the mita compelled mitayos. if they and their families were to survive, to become long-term labourers in the Potosi silver mining industry. Following initial coercion, then, these mitayos-turned-mingas did make choices regarding their work in the mines and their decisions whether or not to remain at Potosi. At the same time, however, the degree of agency was limited by the restrictions of the colonial order. The option for both mingas. and mitayos of returning to their traditional Andean ways was made extremely difficult.

\section{Early Labour Systems During Potosi's First Silver Cycle}

According to Steve Stern. silver mining at Potosi evolved through three important stages. all characterized by different labour systems and particular relationships between Indians and Europeans. " Stern's division of colonial silver mining at Potosi into three stages makes sense because they reflect economic and demographic changes in Potosi as a whole. The first stage began in 1545 when the Spanish discovered silver ore in the cerro rico. the mountain that lies directly south of what became the city of Potosi. ${ }^{12}$ Since the Indian community of Cantumarca was only three kilometres to the west. it is likely that Indians knew the mountain contained silver ore, but it is unclear why they never engaged in mining there. ${ }^{13}$ Indeed, the Incas had been extensively working the Porco mines. thirty-six kilometres south-west of Potosi, at the time of the Spanish conquest. ${ }^{\text {it }}$ One local tradition has it that when men in the service of Huayna Capac. the eleventh monarch of Peru. discovered exposed silver ore on the mountain. a great

\footnotetext{
'Immanuel Wallerstein. "Comments on Stern's Critical Tests." American Historical Review' 93 (1988): 876.

${ }^{10}$ Steve Stem. "Feudalism. Capitalism. and the World System in the Perspective of Latin America and the Caribbean." AHR 93 (1988): 896.

"I Stem. "Feudalism." 850.

12 lbid., 8.

${ }^{13}$ Ibid.. 9.

it lbid.
} 
voice ordered them away, saying that the silver was for their masters. ${ }^{15}$ Some believe that this story is the source of Potosi's name, since "potojch" means "loud noise" in the Incan language. ${ }^{16}$

Regardless of how the silver was discovered, the Spanish crown quickly realized that this desolate place, once described by a sixteenth century Spaniard as "sterile and unproductive, and almost uninhabitable because of its unpleasant and nasty climate. ${ }^{7}$ was potentially a great source of wealth. This potential was heavily tapped during the first twenty-five years of mining (Potosi's first silver cycle). as the richesi silver ores were extracted and refined. Due to the inadequacy of Spanish smelting teclmology at Potosi, the Spanish were dependent on Indians. not only for labour as in later years, but also for their smelting methods. Different theories have been put forward as to why the large Castilian furnaces used by the Spanish in other parts of the empire did not work on Potosi's silver ore. ${ }^{18}$ The shortage of accessible wood to burn in the furnaces was certainly one factor that made the Spanish technology impractical. Consequently, the Spanish were forced to rely on smaller Indian wind ovens called guaras which had been used at the Porco mines and could burn a wider range of fuel sources, including llama dung and yareta. a mossy plant with woody, resinous roots. ${ }^{19}$ Spanish reliance on Indian smelting technology and labour have led historian Jeffrey Cole to argue that during "those early years, the Indians dominated every phase of silier production. " "2" The Spanish also had to sell back to the Indians the ore they received as tribute so that it could be refined by Indians in the guayras. While "domination" might be overstating the Indians' position considerably, some accounts of the period suggest that the Spanish felt the need to improve their bargaining position with the Indian labourers. For example, Stern suggests that one way the Spanish tried to regain some control from the Indians was by dominating the coca trade that was not only an important feature of Andean culture. but also an essential stimulant needed by mine labourers to cope with cold. elevation sickness, and hunger in the mines. ${ }^{\text {i }}$

15 Gwendolin Cobb. "Potosi. a South American Mining Frontier." in Greater America: Essn's in Honor of Herben Eugene Bolton (New York: Book for Libraries Press. 1945). 40.

${ }^{10}$ Ibid.. 40.

17 Bakewell, Miners. 3.

${ }^{18}$ While Bakewell (17) suggests that the "dryness" of the ore was the problem. Cole (3) blames the high altitude for the failure of the Castilian oven.

14 Bakewell. .Miners. 17.

${ }^{20}$ Cole. Porosi llita. 3.

${ }^{21}$ Sten. "Feudalism." 850-851. Coca leaves, the source of cocaine, were chewed by Indian labourers in the mines in order to help cope with the lunger, altitude sickness, cold, and poor air quality that characterized working conditions. It is reported in some contemporary accounts that coca became such a fixture of mining work that it became bad luck for anyone to enter a mine without having some in his mouth. In his Tales of Potosi. 
As word spread about the silver mines at Potosi in the late $1540^{\circ} \mathrm{s}$. both Indians and Europeans alike traveled to the emerging boomtown to take advantage of the remarkable economic opportunities it offered. The first Indian labourers at Potosi were called yanaconas. According to Bakewell. yanaconas were differentiated from hatunrunas. or the common people. because they did not belong to an $a \cdot l l u$, or kin group, the traditional Andean social unit. Before the Spanish conquest. yanaconas could be found on many levels of the social hierarchy, working as herdsmen, craftsmen. temple attendants. or even administrators for the Incan royalty.22 Although the yanaconas were not expected to pay tribute and had more social mobility than hatunrunas. they lacked the social stability characteristic of life in the ayllu. Perhaps this helps to explain why after the conquest the yanaconas quickly developed close ties with the Spanish. It also accounts for why they were quicker than hatunruna Indians to capitalize on the economic opportunities at Potosi. ${ }^{23}$ While Marie Helmer has argued that yanaconas were essentially slaves of the Spanish. others. including Bakewell and Josep M. Barnadas, stress that yanaconas were treated well by the Spanish. enjoying a high degree of freedom and continued exemption from tribute. ${ }^{24}$ Given their success at Potosi during the first quarter century of mining. this latter view seems more tenable.

When silver was discovered at Potosi. it seems that the yanaconas' freedom, their traditional social mobility and flexibility. as well as their ties with the Spanish all contributed to their being the first Indian labourers at Potosí. Soon after 1545, according to Licenciado Juan Polo de Ondegardo. who was the corregidor (Spanish district magistrate) of La Plata and Potosi. over seven thousand yanaconas were working the mines at Potosi. most likely serving the rebel leader. Gonzalo Pizarro and his followers. ${ }^{25}$ Many of these initial yanacona labourers became quite wealthy during the first years of mining. some hiring others to work for them. ${ }^{26}$ Although they always had Spanish masters. the yanaconas were able to make the most of the relationship. due in part to the Spanish reliance on yanacona labour and teclnology. During these initial years. the silver ores were extremely rich, quite accessible. and very plentiful. making it

Bartolome Arzans de Orsua y Vela describes being forced as a ten-year-old to cliew some before entering the Vilacota mine. This tale may be far-fetcled. but the importance of coca to Indian labourers is evident in the fact that one of the first streets in Potosi was named after coca dealers. Bartolome Arzans de Orsua y Vela. Tales of Porosi. ed. R. C. Padden. Trans. Frances M. Lopez-Morillas (Providence. Rhode Island: Browu University Press. 1975). 116-118.

22 Bakewell. Miners. 34-35.

${ }^{23}$ Lewis Hanke. The Imperial Cin of Potosi (The Hague: Martinus Nijhoff. 1956). 39.

${ }^{24}$ Bakewell. Miners. 35.

25 Ibid. 36.

${ }^{26}$ Cobb. Potasi. 47. 
easy for a yanacona to profit. After Pizarro's victory in 1548, thousands of Indians made their way to Potosi. and while some were yanaconas, many more were hatunrunas or encomienda Indians, who were bound in tribute to a Spanish settler. By 1550. a precursor to the Toledan mita had developed as Spanish settlers. or encomenderos, had started to send their encomienda Indians to Potosi to work the mines. ${ }^{27}$

While there is evidence that these encomienda Indians did not mind going to Potosi and saw the mines as an excellent source of tribute money (after all, this initial mita would not have been so different from the mita imposed by the Incas). it is clear that they made up a distinctly different working class than the yanaconas. ${ }^{28}$ Yanaconas were not only able to profit more from the mining, they were also less subject to coercion and poor treatment at the hands of their Spanish and Indian masters, and they had the liberty to leave Potosi whenever they wanted. ${ }^{29}$ Encomienda Indians. on the other hand, were under much greater constraints and suffered far more coercion and abuse.

This dual pattern of labour foreshadowed certain characteristics of the mitayo/minga system that developed later. For example, some yanaconas became indios varas. who were semi-independent miners that rented a certain portion of a mine from its Spanish owner and earned enough to hire their own workers, likely encomienda Indians. ${ }^{30}$ These indios varas developed the specialized skills that would eventually characterize minga workers in later years. The experiences of the yanaconas in general reflected those of the mingas during the mita period, and indeed. the yanaconas of the first silver cycle became the mingas of the second silver cycle and the Toledan mita. There is also evidence that during the $1550 \mathrm{~s}$ and $1560 \mathrm{~s}$. the definition of yanacona was broadened to encompass more Indian labourers. ${ }^{31}$ What likely happened is that encomienda Indians, seeing the relative freedom and wealth of the yanaconas (not to mention the fact they did not have to pay tribute). abandoned their ayllus and became yanaconas themselves.

There was always the danger, however, that these former encomienda Indian would be caught and forcibly repatriated by their curaca (Andean ethnic

${ }^{27}$ Bakewell. . Miners. 45.

${ }^{28}$ Jbid. . $+1-46$. It should be noted. however. that this inquiry into Indian attitudes towards the mita was conducted by Licenciado Polo. himself a mine owner. There are reports of dissatisfied Indians during this early period in Bakewell. but as we shall see in our investigation of the Toledan mita. if the Indians were unhappy with their lot. they likely would have fled. as they did in later years. and the Indian population of Potosi would not have ballooned as much as it did in the 1550's.

${ }^{24} \mathrm{Ibid}$. 46. Many yanaconas. for example. lef Potosi annually to participate in harvest activities. While this travel demonstrates their freedom of movement. $i t$ also suggests that these yanaconas land eaned enough money at Potosi to afford the trip to agricultural regions.

30 Ibid. $19-54$.

$31 \mathrm{lbid} . \mathrm{37}$. 
lord) or encomendero. ${ }^{32}$ Furthermore, the decision to leave their ayllu meant that former encomienda Indians would have to abandon many aspects of Andean culture. such as the communal and reciprocal principles of the ayllu. for their life in Potosi. Potosi was a place where different ethnic groups intermingled. Andean natives, especially yanaconas, were hispanicized to varying degrees. while others formed relationships with Indian women from different cultural backgrounds who would often have children of mixed ancestry: ${ }^{33}$ Some Indian women became involved with Europeans (who came from many parts of Europe. not just Spain), and give birth to mestizos.

Despite the loss of cultural identity (which was endemic during the colonial period), the socioeconomic benefits of working in the mines were considerable. It would likely have been quite difficult for a drafted encomienda Indian working for an indio vara to ignore the disparity between the two working classes, and not at least consider the possibility of joining the yanacona ranks. The other major attraction was the fact that yanaconas did not have to pay tribute. Ironically, while the prospect of a consistent source of income to use in payment of tribute attracted many encomienda Indians to Potosi. the thought of ridding themselves of the tribute burden altogether encouraged these Indians to abandon their encomienda status outright. The socioeconomic mobility enjoyed by these encomienda Indians under the proto-mita of the first silver cycle reflected what would occur later with the mitayos.

The ability of encomienda Indians to leave their estate clearly aggravated encomenderos. just as the subsequent loss of tribute income disturbed the crown, but their freedom to do so in increasing numbers by the $1560^{\circ}$ s not only suggests a decline in the power of encomenderos with respect to Spanish mining interests, but reflects the reliance of Europeans on Indian workers and their technology. ${ }^{34}$ The next section of this paper will examine how technological changes in the Postosi silver mining industry radically altered the relationship between the Spanish and the Indians, leaving the latter in a weaker position. Despite this development, socioeconomic mobility continued to claracterize the Potosi labour system during the next two centuries. as mitayo workers joined the ranks of mingas. Indeed, the existence of this mobility was one of the crucial reasons why the institution of the mita lasted as long as it did. Although the point is often overlooked, the voluntary migration of Indians to Potosi to work in the mines as permanent labourers, and not the institution of a complicated and morally questionable labour draft system. was the ideal situation envisioned by Toledo. ${ }^{35}$ While this voluntary migration did not occur during the second silver cycle as it had during the first. the deplorable conditions of the mita inadvertently

\footnotetext{
32 Ibid.. 48.

${ }^{33}$ lbid. 49.

34 Bbid.. 47.

39 Mid. 66.
} 
led to the gradual growth of a volunteer labour force consisting of former mitayos who abandoned their ayllus to join the minga class in Potosi, which allowed them to take advantage of the benefits associated with being a skilled labourer. The mita continted not only because it provided the mining industry with unskilled Indian workers. but also because it trained Indians who would eventually become skilled labourers. Both types of workers were necessary for the mines of Potosi to survive as long as they did.

\section{Amalgamation and the Development of the Mita}

By the $1570^{\circ}$ s. the rich silver ores that had once lured thousands from around the world to Potosi had become more difficult to find. There was still plenty of silver ore in the mountains. but what remained was of lower quality. As a result, two parallel developments occurred which led to the establishment of the Potosi mita and the restructuring of Spanish-Indian relations. The first development was that as quick profits from the rich silver ores dried up and the amount of work required to generate revenue increased. both yanacona and encomienda Indians left Polosi for other opportunities on farms, ranches, or at other mines. ${ }^{36}$ At the same time. amalgamation techniques using mercury to refine the silver ore became the primary technology used by the Spanish at Potosi. Although amalgamation had been used in Mexico since $1554,{ }^{37}$ the process had not been necessary during the first silver cycle because of the high quality of silver ore mined at Potosi during that period. The higher the quality of silver ore, the greater the amount of mercury required for amalgamation to take place. ${ }^{38}$ Mercury drew pure silver out of the ore as an amalgam of the two elements. Since the amalgam had to be eighty percent mercury and twenty percent silver before the mercury was distilled. high quality silver ore required much more mercun than lower quality ores. Mercury was very expensive, and the supply from Huancavelica. Peru was often erratic, so it made much more economic sense to use the Indian guayra technique, which was more efficient with higher grade ores. ${ }^{39}$ Fucl was also expensive in barren Potosi, and the lower the quality of silver ore. the more fuel was needed by guayras to refine the smaller percentages of silver from the greater amounts of ore. Therefore, as the quality of the ore decreased. amalgamation became more popular, and this led to important changes in the socioeconomic relations between Indians and Europeans.

\footnotetext{
30 Cole. Porosi Mira. 4.

i7 Ibid.. 4.

is Bakewell. Miners. 18.

34 Ibid., 19-2?.
} 
Amalgamation required a great deal of capital investment as well as Indian labour. ${ }^{+0}$ The capital investment included building water mills for grinding the silver ore (ore had to be ground before it was mixed with mercury). constructing dams and artificial lakes to ensure a constant supply of water during the dry season, and the importation of mercury itself. ${ }^{+1}$ While some Spaniards had sufficient capital for these types of projects. Indians did not. and as a result they were unable to maintain the favourable position they had occupied in their relationship with Spaniards during the first silver cycle. ${ }^{42}$ Even the relatively independent indios varas were relegated to the position of wage labourers. ${ }^{\text {t3 }}$ Indian labour was required by the Spanish not only to work the mines and refine the silver ore, but also to construct the many mills. dams. and artificial lakes required in the amalgamation process. The problem was how to find a steady source of Indian labourers willing to work in the mines. since assurance of a stable workforce was needed before Spanish investors would be willing to provide the capital for switching over to amalgamation. "Whereas 5000 Indians working were in the mines in 1551, ten years later only 300 remained to mine the lower quality silver ore. ${ }^{+5}$ The solution to this problem was the mita instituted by Viceroy Francisco de Toledo.

The mita system devised by Viceroy Toledo in 1573 was loosely modeled on a draft labour system called the mita, which the Incas had imposed on their subject populations (primarily the Aymara Indians. the same group targeted by the Potosi mita) in order to insure sufficient labour for public works projects ${ }^{\$ 6}$ and seasonal agricultural enterprises. ${ }^{47}$ The Toledan mita recruited Indians from widely disparate cultural, geographic, and socioeconomic backgrounds. ${ }^{+8}$ While

\footnotetext{
${ }^{10}$ Cole. Potosi Mira. 18.

4 Brading and Cross. "Colonial Silver Mining." 553.

$\$ 2$ A hierarchical system of ownership developed among those Spaniards involved in silver mining. At the bottom were the $\mathbf{5 0 0}$ mine owners. none of whom controlled more than fifty mitayos. Above them were the seventy-five azogueros. the owners of the refining mills or ingenios. as well as mines. and in the top position were the dozen silver merchants who minted the silver bars and provided credit for mining and refining projects. The azogueros were the most powerful of these three groups. especially after the formation of the Banco de San Carlos in 1751. which bought silver bar and provided financing. The bank sparked competition among the silver merchants. thus increasing the influence of the azogueros. Ibid., 567.

${ }^{43}$ Ricardo A. Godoy. Mining and Agriculture in Highland Bolivia (Tucson: The University of Arizona Press. 1990). 89.

th Cole. Porosi Mitia. 17.

4s Bbid. 4.

${ }^{46}$ Rowe. "The Incas." 170.

${ }^{47}$ Brooke Larson. Cochabamba, 1550-1900: Colonialism and tgrarian Transformation in Bolivia (London: Duke University Press. 1998). 60.

${ }^{48}$ Brading and Cross. "Colonial Silver Mining." 560.
} 
some came from highland altiplanos and would have been used to a physical environment similar to Potosi. others came from lower valleys like those in Cochabamba and had to adjust to elevation and climatic differences. Indians in agricultural areas like Cocliabamba also suffered more because the loss of ablebodied men to the mita disrupted agricultural cycles. ${ }^{+9}$ As with the proto-mita of the first silver cycle. those Indians who were accustomed to similar environmental conditions fared better. Although the lack of Indian labour due to the depletion of rich silver ores and the adoption of amalgamation were the primary reasons for the development of the mita. Toledo had other reasons for adopting it. These included the fact that Indians were viewed as the only group able to physically survive the work in the mines, and that the mita provided a unique opportunity for converting Indians to Christianity. ${ }^{50}$

The Spaniards believed that Indians were the only suitable workers for Potosi because. as Viceroy Conde de Nieva put it in 1563, Spaniards would "rather die of liunger than take a hoe in their hands," and black slaves simply perished in the high altitude and cold conditions. ${ }^{\text {s1 }}$ The Spanish crown saw conversion of the Indians to Christianity as a justification for imposing the mita. Phillip II approved the use of the forced labour system in a 1589 declaration, saying that so long as the Indians received religious teaching, justice, food, good wages. and health care. then forced labour would be in the Indians' best interest. since it would promote their conversion to Christianity. "Without an Indian labour regime. he conjectured, the mines could not be exploited, Spaniards would not settle in the region. and the Indians would not be converted. Of course, the primary goal of increasing revenues for the royal treasury goes without saying. Spanish officials clebated the morality of the mita throughout its history. ${ }^{53}$ Toledo himself lad mixed feelings about the mita. He was disappointed by the lack of Indian interest in mining in the 1570's and saw the need for a labor regime, but was dismayed by the greed of the Spanish mine owners and azogueros (who owned boll mines and relining mills). ${ }^{54}$ About one hundred years later, Viceroy Conde de Lemos tried in vain to abolish the mita, but his reasons were more political than moral. ${ }^{\$ 5}$ Whatever the Spanish motives for the mita, it was clearly a coercive system that devastated Indian communities, abused workers, and caused enormous changes to the traditional Andean social systems.

\footnotetext{
+" Bakewell. Miners. 110

9) Ibid. 64.

5 Ibid.. 56.

$\therefore$ Ibid.. 82.

${ }^{3}$ Colc. Porosi Mita. 2.

"Bakewell. Miners. 74.

"Jeffrey A. Cole. "An Abolitionism Bom of Frustration: Conde de Lemos and the Potosi Mira. 1667-1673," H.AHR 63 (1983): 332.
} 
The period from the beginning of the mita in 1573 to the early 1600 s represents Stern's second stage of mining at Potosi. ${ }^{56}$ This stage was characterized by a massive expansion of silver extraction and refining and huge profits for the Spanish miners, azogueros, and silver merchants. Indeed. Stern agrees with Wallerstein that during this period "coerced cash crop labour" (represented by the mitayos) existed in Potosi and "worked wonders" for Spanish investors. ${ }^{37}$ Miners concentrated on extracting and refining lower grade silver ore that had been left as tailings during the first silver cycle. when higher grade ore was desired. The lower quality of ore at Potosi was ideal for the amalgamation process, and the ease of extracting it contributed to the virtual elimination of German silver mines from the European market by the end of the sixteenth century. ${ }^{58}$ Potosi was soon the richest city in the new world (as reflected in the saying "as rich as Potosi"), and by the middle of the seventeenth century. it had grown to a population of 160.000 . making it not only the largest city in the Americas. but larger than most European cities as well. ${ }^{34}$ It was called the Imperial City by Emperor Charles V, and boasted fourteen dance halls. thirty-six gambling houses, a circus, and during festivals. fountains that sprayed wine and chicha, an alcoholic beverage made from maize. ${ }^{60}$ Needless to say. much of this opulence was due to the labour of mitayos in the mines and in the refineries.

Mitayos in Potosi were part of a rather complicated labour system. They performed their mita duties in the mines or refineries for one week out of every three during the year they were required to spend in Potosí. This week of labour usually required living on site at a work camp from Monday to Saturday. The two weeks they spent "resting." or de huelga, were primarily devoted to finding other sources of income, since their wages were not high enough to cover the cost of living in Potosi. ${ }^{61}$ While some mitayos worked in the city selling goods or employed as servants. most returned to the mines during their de huelga to work as voluntary labourers, or mingas. Mitayos who worked as mingas while taking de huelga were distinguished from the minga workers who either had their roots in the yanacona class or had escaped the Potosi mita. The former were at a disadvantage in terms of job type, working conditions. treatment by supervisors. pay. and the amount of power they held in the employer-employee relationship.

\footnotetext{
\$6 Stern. "Feudalism." 851.

57 Ibid.

${ }^{58}$ Larson. Cochabamba. 58.

${ }^{30}$ Arzans. Tales of Polosi. XIII.

${ }^{60}$ Hanke. The Imperial Cin' of Potosi. 2.

${ }^{61}$ Cobb. Potosi, 30.
} 
Mitayos of Potosi usually worked as apiris, with the unenviable task of carrying Iwenty-five kilogram sacks of ore up rope ladders from the heart of the mine to the surface. a distance in some cases of three hundred metres. ${ }^{62}$ While Toledo had ordered that apiris make only two of these trips per day (due to the cold. poor air quality. and perpetual darkness in the mine shafts, not to mention extreme plysical exertion). by the $1580^{\circ}$, some would have to make twenty-five trips daily. and by the $1590^{\circ} \mathrm{s}$ a quota was set at nineteen trips per day. ${ }^{63}$ It is not surprising that permanent mingas (that is, mingas who were not de huelga mitayos) refused to do this work. Instead, the permanent mingas worked in the mines as barreteros. the labourers who picked the silver ore from the rock wall deep inside the mine. It is likely that the vast majority of mingas who were reported to be working as apiris were actually de huelga mitayos. ${ }^{\text {64 }}$ In other words. mitayos would work primarily as apiris whether they were de huelga or not. and mingas would work as barreteros.

Different jobs meant different working conditions, and as a rule, mitayos in all phases of silver production worked under much more oppressive conditions than mingas. Not only was their work in the mines harder, but the grinding of silver ore they did at the mills was also more strenuous and unhealthy. Mingas refused to work as grinders. or morteros, in part because it was grueling, and in part because of the hazardous dust created by the grinding process, which caused a lung disease called choco. ${ }^{65}$ Morteros and other refinery workers also suffered poisoning from lead and mercury exposure, and although the ill affects of these substances must have been recognized, they were not of great concern to mine owners. ${ }^{\text {sh }}$ Furthernore, apiris and other mitayos were beaten, whipped, stoned, insulted. and underfed by the moyordomos and pongos (the respective names for Spanish and Indian work supervisors). ${ }^{67}$ Accounts of mitayos being abused were reported by Anton Zacharias Helms in $1789,{ }^{68}$ despite the fact that just a few years had passed since the Tupac Amuru rebellion of the early 1780s, which was due in part to the abuses of the mita. ${ }^{69}$ Mine owners sought deliberately to prevent mitayos of the same hometown from working together. with the result that

"2: Cole. Potosi Ifita. 24. Other provisions were put in place to ease the suffering of mitayos. but like Toledo's guidelines restricting the work of apiris. they were often ignored after a token period of acceptance. Bakewell. M/iners, 169-173.

${ }^{\text {"3 }}$ Cole. Potosi . Mina. 24.

in Bakewell. Miners. 121.

"Enrique Tandeter. "Forced and Free l.abour in Late Colonial Potosi." Past and Present 93 (1981): 110.

"Bakewell. Ifiners. 148.

${ }^{67}$ Ibid.. 1+2-1+5.

${ }^{\text {"n }}$ Anton Zacharias Helms. Tranels from Buenos Ayres, by Potosi fo Lima (London: Printed for Richard Phillips by J. G. Bamard. 1807), v.

${ }^{n}$ J. R. Fisher. Silver Mines and Silver Miners in Colonial Per» (Liverpool: Centre for Latin American Studies. 1977). 91. 
linguistic and cultural barriers between labourers made the work lonely and resistance to the oppression very difficult. ${ }^{70}$ Mingas. on the other hand. were treated better by their supervisors. worked fewer hours. had better working conditions, and performed lighter tasks. ${ }^{71}$ Some historians have also stressed that since mingas were in such high demand. they were. as a rule. an unruly labour force when compared to the mitayos, who toiled in "ultimate submission."72 Whether this description of mingas is fair or simply reflects the critical views of employers is difficult to say.

Even without human abuse, the work itself was extremely hazardous. In 1559. Viceroy Andres Hurtado de Mendoza drew up a provision that would send Indian prisoners who were condemned to death to work in the Potosi mines. ${ }^{73}$ Mendoza's provision is telling, since it was only intended as a punishment and not as a way to increase the labour supply at Potosi. At the time. guayras were still the primary means of refining silver ore rather than the labour-intensive amalgamation process, so there was not yet a serious labour shortage. Many accounts exist that describe how hazardous mine work was. although some are exaggerated. Friar Antonio de la Calanchas. for example. asserted in 1638 or 1639 that ten Indians died for every peso of silver that was produced. and other accounts call cerro rico "the man-eating mountain." saying that the dangers of the mita itself, and not migration, caused the decline in mitayo numbers. ${ }^{74}$ While these claims stretch cedulity. conservative estimates suggest that during the two and a half centuries of the Potosi mita. many thousands of mitayos died of accidents and disease due to their hazardous work environment. ${ }^{75}$

High as the number of fatalities at Potosi was. it paled in comparison to the mita at the Huancavelica mercury mine to the north. Mothers reportedly maimed their sons to exempt them from the Huancavelica mita. and a mitayo was lucky to survive the two month stint at the mercury mines. ${ }^{76}$ Whitaker describes the Huancavelica labour regime as "the evils of the mita at its worst." with poisoning from mercury exposure and carbon monoxide gas. as well as pneumonia and cave-ins all contributing to a horrific working environment. ${ }^{77}$ Nevertheless. working as a mitayo at Potosi was bad enough. and it was not

\footnotetext{
${ }^{70}$ Bakewell. Miners, 95.

71 bid. 133.

72 Tandeter. "Forced and Free Labor." 134.

${ }^{73}$ Hanke. The Imperial Cin' of Polasi. 25.

${ }^{74}$ Cole. Potosi Mfita. 26.

${ }^{73}$ Fisher, Silver Mines, 9.
}

${ }^{76}$ Kendall W. Brown. "Worker's Health and Colonial Mercury Mining at Huancavelica. Peru." The Americas 57 (2001): $\mathbf{4 7 0 .}$

${ }^{77}$ Arthur Whitaker. The Huancavelica Mercury Mine (Cambridge: Harvard University Press. 1941). 18-19. 
without reason that the mines were called "a mouth of Hell, ${ }^{, 78}$ and the summons to labour there came to be viewed as "a virtual death warrant." ${ }^{79}$ Mingas, however. were not subject to such harsh working conditions; though they suffered from the cold. poor air quality, and cave-ins, their position as skilled labourers secured them more time off and higher remuneration as well. ${ }^{80}$

\section{Rates of Pay and Living Conditions}

After the initial capital invested by the azogueros to set up the amalgamation system. the greatest expense for Spanish mining interests consisted of wages and salaries. ${ }^{81}$ Not surprisingly, wages for the work done by mitayos were low. and they remained stagnant for most of the mita's history." Assuming that wages were paid on time. a single mitayo eamed just enough to pay for food. ${ }^{83}$ But most mitayos did not come to Potosi alone. As of 1600 , three quarters of them arrived married and with families, ${ }^{84}$ meaning that in 1608 , wages covered only one-third of the average mitayos' expenses. ${ }^{85}$ These expenses included not only food. clothing. and shelter. but also tributes, levies, hospital fees, funeral services. and the costs of travel back to the home province once the year of service was finished. ${ }^{86}$ Mitayos attempted to make up the difference in a number of ways. often by getting the entire family involved in economic activities.

The wives of mitayos engaged in a variety of tasks in order to earn income. many of them directly tied to the mining industry. Some worked as cooks for mine owners. ${ }^{87}$ but many more were employed as pallires, or sorters of ore. ${ }^{88}$ Others operated the guayras used for smelting silver ore that was then sold as rescates. or purified silver. ${ }^{89}$ Women also involved themselves in market activity by selling goods from their home provinces as well as other products. ${ }^{90}$

\footnotetext{
"Hanke. The Imperial Cin of Potasi, 25.

Arzans. Tales of Polosi. XIX.

${ }^{80}$ Bakewell. Miners. 122.

${ }^{81}$ Richard L. Ganıer. "Long-Term Silver Mining Trends in Spanish America," AHR 93 (1988): 923.

$"$ Rowe. "The Incas." 173.

8 : Bakewell. Miners. 104.

${ }^{8+}$ Bianca Premo. "From the Pockets of Women: The Gendering of the Mita, Migration, and Tribute in Colonial Chucuito. Peru." The Americas 57 (2000): 73.

Bs Bakewell. . Miners. 105.

soid. I04

${ }^{87}$ Tandeter. "Forced and Free Labour," 118.

${ }^{88}$ Bakewell. Miners. 139.

"Stern. "Stern's Reply," 887.

"0) Premo. "From the Pockets of Women." 85.
} 
The produce. llamas, and cloth brought from home and sold at the Potosi markets represented another form of subsidy by the mitayos. since all of the profits earned stayed in the Imperial City or helped to pay for the long journey home. The mitayos and their families usually returned to their provinces empty-handed. though there were some exceptions. For instance, mitayo families from the cattle and tallow producing regions of Caminaca and Achaya stayed in Potosi even longer than their allotted year to sell tallow for candles. if the economic opportunities were good. ${ }^{11}$ This influx of goods helped to stimulate commerce in Potosi and constituted another reason for continuing the mita." Finally; children also worked to supplement the family's income. the sons often as messengers and the daughters as spinners. ${ }^{93}$

Despite these efforts to supplement their income. most mitayo families still had to endure difficult living conditions. It should be noted. however. that life in Potosi up until the seventeenth century had its difficulties even for the rich. For instance, the high altitude and chilly climate were especially hard on infants. Expectant European mothers would go to the warmer valleys for confinement. since prior to the seventeenth century almost no infants born in Potosi survived past two weeks. ${ }^{94}$ Illness was endemic to all sectors of the society due to the constant influx of new residents bearing all kinds of viruses and bacteria. but it was especially prevalent among the Indians living in their cramped section of the city. ${ }^{95}$ This part of Potosi was called the Indian quarter: separated from the rest of the city by a canal built for the water mills, it sat in the shadow of the mountain. Not only were the huts in the Indian quarter crowded with twenty to thirty inhabitants each and in need of repair, but the area soon became a ghetto. attracting fugitives, criminals. prostitutes, alcoholics, homosexuals. the poor. and other undesirables of various nationalities. ${ }^{96}$ Many of the gang fights. assassinations, and duels described in Arzans ${ }^{\circ}$ Tales of Potosi probably took place in the Indian quarter. The large numbers of Ilamas (up to ten per labourer) and other livestock brought to Potosi by mitayo families in order to survive the year is another indication that sanitation was poor. A typical meal for a mitayo would consist of "scanty [portions] of potatoes and maize boiled in water. ${ }^{47}$ The living conditions notwithstanding. Potosi also boasted all of the luxuries. vices. and entertainment of a major European city and even humble mitayos would be able to experience the excitement provided by civic festivals and celebrations.

\footnotetext{
"I Tandeter, "Forced and Free Labour." 132.

${ }^{92}$ Cole. Potosi Mita, 17.

${ }^{03}$ Tandeter. "Forced and Free Labour." 118.

os Arzans. Tales of Potosi. XVII.

${ }^{\circ 5}$ Bakewell, Mfiners, 110.

\% Arzans. Tales of Polosi. XXIII.

${ }^{\circ 7}$ Helms. Tranels from Buenos Aryes. 14.
} 
Acarele du Biscay reported in 1658 that during fiestas, Indians were richly dressed and were often an important part of civic ceremonies. ${ }^{98}$

Mingas could earn enough to participate in Potosi's night life, but not if the wages for mining were the extent of their total income. They made up to three times more than mitayos (depending on the year in question and the specific job they did). but it is estimated that their wages only provided half of what they needed to survive. ${ }^{99}$ Mingas supplemented their wages, however, by shares of silver ore. or corpa. Some of the corpa that mingas received were added to their wages by mine owners. but another source was the independent mining conducted by mingas on the weekend. ${ }^{101}$ In addition, some smuggled silver ore out of the mines illegally at the end of a day's work. ${ }^{101}$ Mingas who engaged in this practice were called kajcheos. or silver thieves. Since there was little supervision of mingas working as barreteros, they were able to smuggle out the highest quality ore or leave it to be mined on the weekend. ${ }^{102}$ Mingas took the corpa to the ghatu, the Indian ore market, where it was sold and later refined by Indians (often women) using gualyras.

Althougl Spanish miners considered these last two sources of corpa illegal. mingas felt that corpa was their right, and since the demand for minga labour remained high, it was difficult for miners to do much about weekend mining and the smuggling of ore. ${ }^{163}$ Mingas were also reported to have defended their weekend mining of the corpa by rolling boulders onto the representatives of azogueros who tried to prevent them from continuing the practice of kapcha (collecting the corpa). ${ }^{104}$ As the number of mitayos declined in the seventeenth century due to disease and migration. they too were able to take advantage of the right to corpa and participaled in weekend mining and daily smuggling. ${ }^{105}$ Even when the practice of kapcha was discouraged by the azogueros, mitayos often had little choice but to engage in it in order to feed themselves and their families and to avoid large debt loads. The corpa not only became the most valuable source of income for mingas and mitayos. it also grew to be twenty-five percent of the total silver produced at Potosi. ${ }^{\text {Ith }}$

\footnotetext{
${ }^{48}$ Irving A. Leonard. Colonial Travelers in Latin America (New York: Alfred A. Knopf. 1972). 141.

Rowe. "The Incas." 173.

${ }^{100}$ Slonre agrements arose in Mexico as well, and just as in Potosí, the Mexican mine worker's particlo represented the most important part of his wage. Stern, “Feudalism." 856.

${ }^{101}$ Cobb. Potosi. 49.

102 Tandeter. "Forced and Free Labour." 134.

${ }^{103}$ Stem. "Feudalisın." 852.

${ }^{104}$ Godoy, Ifining and Agriculnure. 90.

105 Stem. "Stenis Reply." 887.

lok Steml. "Feudalism." 852.
} 
The lure of corpa silver was further enhanced by the fact that it avoided the requisite twenty percent tax by the crown. Obviously the need for labourers at Potosi must have been great. considering that such a large amount of silver was allowed to go untaxed. This situation reflected the determination of the colonial government to keep the mines at Potosí running no matter the cost. and their recognition that a constant supply of both skilled and unskilled Indian labour was necessary for the task. Officials believed that even though the mines had peaked at the beginning of the seventeenth century, there was always the chance that boom times would return if richer veins were struck. labour became more reliable, or production techniques grew more efficient. Therefore. Spain's willingness to ignore the taxes lost through rescates indicates the lengths to which they were willing to go to retain Indian labour.

\section{Spanish Abuses of the Potosi Mita and Indian Alternatives}

Mine owners and azogueros sought to make up losses from the corpa and other costs by abusing the mita system. Such abuse increased during what Stern calls the third phase of silver mining. which began early in the seventeenth century. This third phase was marked by a decrease of easily attainable silver ore for the amalgamation process, a drop in the quality of ore in general. population decline in Potosi, and mutation of the mita from a form of labour for the mines into a source of labour subsidy. ${ }^{107}$ This change in the mita is exemplified by the indios de faltriquera. or pocket Indians, which were cash payments made by curacas to mine owners and azogueros to compensate for unaccounted mitayos from their ayllu.

During the seventeenth century, the number of mitayos traveling to Potosi had dropped for a number of reasons. Disease. a disastrous legacy of the Conquest. ${ }^{108}$ was one of them. but another was the psychological impact of the Conquest. which led to low birth rates. Indians sexual relationships with Europeans and Africans led to increasing numbers of mestizos and mulattos. and decreased the number of pure-blood Indians being borm. ${ }^{109}$ Finally. many Indians simply fled the mita by migrating out of the subject provinces or by becoming voluntary labourers at Potosi. ${ }^{110}$ When the Potosi mita first started in 1573.

\footnotetext{
${ }^{107}$ Ibid., 851.

108 Disease continued to affect Potosi in the eighteenth century. An influenza epidemic in 1719 killed 22.000 people in Potosi and led to the census of 1725-1740. Adrian J. Pearce. "The Peruvian Population Census of 1725-1740." Latin American Research Review 36 (2001): 69.

${ }^{100}$ Cole. Potosi Mita. 28.

${ }^{110}$ Bakewell. Miners, 108-109.
} 
13.500 mitayos came to Potosi from provinces as far as one thousand kilometres away. By 1690 . the number had dropped to two thousand. "II Instead of increasing the numbers of mitayos required to participate in the draft to adjust for the decline in population. mine owners and azogueros demanded that they be recompensed for missing mitayos with enough money from the subject province to pay for a minga replacement worker.

Despite claims by mine owners and azogueros that they used the indios de faltriquera to pay for mingos, it often went to increase their profits, pay for non-production costs (such as repairs and improvements), and cushion the fluctuation in cost of supplies. especially mercury. "2 Moreover, even if the money was used to pay for labour, often cheaper mitayos were employed, despite the fact that owners had been recompensed with enough money to pay for a more expensive minga worker. In 1650. for example. only twenty percent of the requisite mitayos arrived in Potosi, half of them paid for by the indios de faltriquera. ${ }^{113}$ Indios de faltriquera was illegal, but some have argued that it subsidized the higher pay of mingas and attracted voluntary workers to Potosi. thus providing Indians with economic opportunities. ${ }^{11}$ This may have been the case. but it must be remembered that it was the provinces subject to the mita that were responsible for paying this subsidy. Thus. Indians not only had to provide the forced labour for the mines, they also had to help pay for voluntary or minga labour. Furthermore. though the practice of indios de faltriquera was intended to prevent mitay os from fleeing the mita. in reality it increased the pressure on mita communities. and thus forced more mitayos to migrate outside of their ayllus. ${ }^{115}$

Abuses of the mita tended to increase as the productivity of the Potosi mines dropped and the number of milayos reporting to Potosi declined. Mitayos were made to take the brunt of increasing production costs, overextension in construction during boom times, ill-spent profits, and the declining quality of silver ore. "As the massive levels of production eased off at the end of the sixteenth century. mine owners and azogueros introduced quotas for mitayos, refused to pay travel allowances, and withheld wages. ${ }^{17}$ Mitayos would be forced to work until their quota was filled. and were often forced to hire mingas or even get their wives and children to help them meet their quotas. ${ }^{118}$ Azogueros would also "rent" or "sell" old. feeble, or uncooperative mitayos to other mining camps.

\footnotetext{
${ }^{111}$ Herbert S. Stein. Bolivia: The Evolution of a Mfulti-Ethmic Society' (New York: Oxford University Press. 1982). 64-65.

"1: Cole. "Abolitionism," $311-312$.

113 Bakewell, Ifiners, 106.

114 Cole. Polosi Mita. 57.

11s Premo. "From the Pockets of Women." 83.

${ }^{110}$ Cole. Porosi Mira. 25.

${ }^{119}$ lbid.. 28.

118 Tandeter. "Foreed and Free Labour," 117.
} 
textile mills, or farms, keeping the best workers for the refineries. ${ }^{119}$ Mine owners even forced apiris to pay for the candles and sacks they needed to do their jobs in the mines in an effort to cut production costs and increase their profit margin. ${ }^{120}$ The mining elite in Potosi viewed the mitayo purely as a subsidy from which they sought to squeeze as much as possible.

Though the Indians subject to the Potosi mita were exploited by the Spanish. it would be a mistake to assume that they passirely accepted their fate. Evidence of Indian agency has been a key aspect of the revisionist Latin American history that has emerged since the 1980s. Historian Jeremy Baskes. for example, provides a provocative re-interpretation of the repartimiento in late colonial Oaxaca. In reaction to traditional historiography that stresses the victimization of Indians with regards to the repartimiento. Baskes claims instead that the repartimiento provided Oaxacan Indians with credit in order to engage in the lucrative grana cochinilla or crimson red dye trade. ${ }^{121}$ Other historical works. such as one edited by Brooke Larson. Olivia Harris. and Enrique Tandeter and another edited by Susan Schroeder, also provide evidence of Indian agency. ${ }^{122}$ While this revisionist approach is beneficial, it is important for historians of Latin America to realize that the expression of agency or resistance was a very relative phenomenon. While some agency might result in armed rebellion or making claims in colonial courts, other forms of resistance were much more passive and sometimes. especially during periods of extreme infectious epidemics. it faded to nearly nothing at all. ${ }^{123}$

Mitayos and their families exercised some measure of control over their circumstances by choosing whether or not to comply with the mandatory draft. Many of them went to great lengths to escape the Potosi mita. For instance. when Viceroy Palata reformed the mita to include new geographical regions and formerly exempt Indians like forasteros (Indians who had moved from their original kin group), the newly subject Indians fled into areas outside of the viceregal administration, including the yumgas (lowlands). In many cases, chacareros and estancieros (Spanish farm owners and ranchers) were willing to

\footnotetext{
${ }^{110}$ Cole. Porosi Mfisa. 25-26.

${ }^{120}$ Bakewell, Miners, 152.

121 Jeremy Baskes. Indians, Merchants, and Markets: A Reinterpretation of the Repartimiento and Spanish-Indian Economic Relations in Colonial Oaxaca. 1750-1821 (Stanford: Stanford University Press, 2000). 1-6.

122 Brooke Larson. Olivia Harris. and Enrique Tandeter, eds.. Elhuicin: Markets and Migration in the Andes: At the Crossronds of History and Awhropologn (London: Duke University Press. 1995): Susan Schroeder. ed.. Native Resistance and the Par Colonial in Ne1. Spain (London: University of Nebraska Press. 1998).

${ }^{123}$ Ronald Spores, "Differential Responses to Colonial Control among the Mixtecs and Zapotecs of Oaxaca." in Susan Schroeder (ed. ) Native Resistance and the Par Colonial in New' Spain (London: University of Nebraska Press. 1998). 30.
} 
protect mitayos from being caught because they needed Indian labour as well. ${ }^{124}$ More than a simple geographic re-location, a migration of this magnitude involved drastic social, economic, cultural, political, and environmental adjustments. The willingness of Indians to migrate in order to avoid the mita is even more intriguing in light of evidence suggesting that Mexican Indians from Michoacan voluntarily left their lands to work in the mines of Pachuca and Zacaltecas. ${ }^{123}$

Understanding why Mexican Indians continued to be attracted by the silver mines at Pachuca and Zacatecas while Andean Indians fled from Potosí towards the end of the first silver cycle is central to understanding the Potosi mita. Indian adaptation to colonialism, and the nature of Indian agency. Simply put. Mexican Indians migrated to the mines for the same reasons that both yanaconas and encomienda Indians traveled to Potosi during the first silver cycle: to take advantage of the economic opportunities provided by the boom in the American silier industry. While the greater Indian population around the Mexican mines and the use of a small number of African slaves certainly helped the Mexican silver industry address their labour concerns, the consistent production of Mexican mines, as opposed to boom and bust cycle of Potosi, ensured that the Indian labourers would stay. ${ }^{126}$ Mexican miners retained a relatively generous share of silver ore. or partido, as part of their wages and were usually not in debt. While there had been a draft labour system for the mines in New Spain called the repartmiento de mita, voluntary labourers had always outnumbered draft labourers, and by the middle of the seventeenth century, the importance of the repartmiento in New Spain had faded. ${ }^{127}$ Moreover, New Spain lacked the Incan tradition of mita and an administrator like Toledo to put a comprehensive and enduring labour regime in place. ${ }^{128}$ The critical difference. however. is that New Spain did not require the subsidization of a long term repartmiento de mita because its silver mining industry was much more economically stable than Potosi's, and thus it was easier to maintain a steady labour force.

${ }^{124}$ Cole. Potosi Mlira. 27.

123 Brading and Cross. "Colonial Silver Mining." 559.

${ }^{126}$ Gamer. "Long-tenm Silver Mining Trends," 927-928. Gamer also mentions that both the higher ore content and cheaper and more reliable supply of mercury from Almaden. Spain contributed to the stability of the Mexican silver industry. Brading and Cross also add that the Mexican silver industry benefited from the greater capital resources and resulting financial well-being of Mexican mine owners. as well as the fact that New Spain was favoured by the Spanish crown. Brading and Cross, "Colonial Silver Mining." 567 and 576.

${ }^{127}$ Bradiug and Cross. "Colonial Silver Mining. 557.

128 Bakewell. Miners. 184. 
The silver mines at Oruro. Peru often attracted labourers from Potosi because they offered higher wages, better weather. lower altitude. and shallower mine shafts. ${ }^{129}$ The reason that the mita constituted a necessan monetany and labour subsidy for Potosi was that the mines did not offer enough economic incentives after the first silver cycle for Indians to be attracted to work there. The willingness of Indians to work at the Oruro mines demonstrates that given decent economic prospects and satisfactory working conditions. Indians would voluntarily seek employment in the silver mines. The flow of Indian labour to silver mines in Oruro and New Spain (not to mention Potosi during the first silver cycle) also reveals that in spite of the calamitous European impact on local society. Indians still exercised agency in how they adapted to the changing socioeconomic circumstances they faced. Unfortunately for Toledo. whose ultimate goal had been to attract rather than force Indians to the mines. Potosi failed to lure enough workers and so the mita became not only a source of labour. but a crucial subsidy as well. Except for the remnants of the yanaconas who had started working at Potosi when it was still lucrative for Indians. most mingas did not first enter the mines voluntarily. Rather. their ranks swelled with former mitayos who had made the decision to stay in the Imperial City.

Flight from the mita was often not an escape from mine work. Many mitayos stayed in the Imperial City after their year of servitude was finished to work as mingas, becoming citizens of Potosi and enjoying exemption from the mita and from tribute obligations. ${ }^{130}$ When there were serious shortages of free labourers, city authorities helped to conceal mitayos who had chosen to stay in Potosi from their curacas, who were eager to avoid paying to replace the missing worker in the form of an indios de faltriquera. Flight was the easiest option for mitayos intending to stay in Potosi . since the cost of clanging residence legitimately could be as high as 70 pesos. ${ }^{131} \mathrm{~A}$ milayo would have difficulty saving up that much money, since he earned at most 130 pesos a year. which was barely sufficient to supply an unmarried mitayo with his basic needs. Many chose to stay in order to pay off the debts they accumulated through taxes. fees. and the high cost of living. Indeed, it is likely that civic officials and mining interests would have actively encouraged mitayos to accumulate debt so that they would become part of the permanent work force.

For mitayos, to settle in Potosi was a mixed blessing. since the socioeconomic benefits of minga work were offset by losing the communal security provided by the ayllu. or kin group. Arzans and Temple have found that Indians were. by and large, valued by all races as contributing members of the

\footnotetext{
${ }^{120}$ Stein. Bolivia. 58.

${ }^{130}$ Cole. Potosi Mita. 26.

131 Tandeter, "Forced and Free Labour." 126 and 131.
} 
Potosi community. ${ }^{132}$ Larson notes that the health problems associated with mine work. wheller as an apiri or a barretero, were significant, and that mine work, in general. was much worse than agricultural work. ${ }^{133}$ Cole contradicts the latter part of Larson's statement. saying that the work most Indians did in their home provinces was just as arduous as mine work. ${ }^{134}$ Many mitayos in Potosi took jobs outside of the mines as carpenters. tailors. and domestic servants. ${ }^{135}$ It seems reasonable to argue that the decision to work in the mines, in the city, or on a hacienda was based. to a greater or lesser degree, on Indian preference. Mitayos from geographical areas similar to Potosi who were drawn by the profits available there for mingas would be happy to stay in the Imperial City, while Indians from the lower valleys might take their first opportunity to return to a more pleasing climate and to the agricultural or ranch work that they enjoyed. If the existence of Indian agency is accepted by historians, as it is by both Cole and Larson, then it makes sense to extend it to these types of decisions. Mitayos may not have asked to be part of the Potosi labour draft, but they did have the power to choose whether they would go. whether they would stay, and whether they would retum.

\section{Conclusion}

The Potosi mita was a remarkable institution subsidizing not only mining interests. but the golden age of Spain itself. The burden of the labour regime. however. was placed squarely on the backs of the mitayos and their families. as well as on the communities that were depopulated by the flight of Indians from the mita and forced to pay replacement fees for them. The migration of mitayo fanilies from mita provinces and the cultural mixing that followed produced fundamental changes in the traditional Andean way of life.

Although the Andean Indians suffered as a result of the mita, it is clear that they also exhibited agency and were able to decide for themselves whether they would participate in the mita or attempt to escape it. One of the most important results of this agency for Potosi was the fact that so many mitayos chose to become mingas and remain at the mines. In effect, the primary source of minga labour throughout the three stages of silver mining at Potosi was the mita itself. Throughout the history of the Potosi mines, there was a dual labour force consisting of voluntary and forced labour. A claracteristic of this arrangement was that forced labourers often made socioeconomically-based decisions to join

\footnotetext{
132 Arzans. Tales of Potosi. 168-169: Edmond Temple. Travels in Various Parts of Peru. Including $a$ lean's Residence in Potosi Vols. 1 and 2 (New York: AMS Press, 1971). 185.

133 Larson. Coclubamba. 319.

${ }^{134}$ Cole. Potosi I/ira. 26.

135 Bakewell. Miners. 112.
} 
the ranks of voluntary labourers. whether as yanaconas or mingas. The disparity in working conditions experienced by voluntary and forced labourers. the debts accumulated by mitayos during their stay at Potosi. and the hardship of the long journey home all induced mitayos to stay in the Imperial City and work as mingas. Therefore, the mita not only subsidized the silver mines. it also provided the voluntary. skilled, and permanent labour force that Toledo and other Spanish officials desired from the start. 